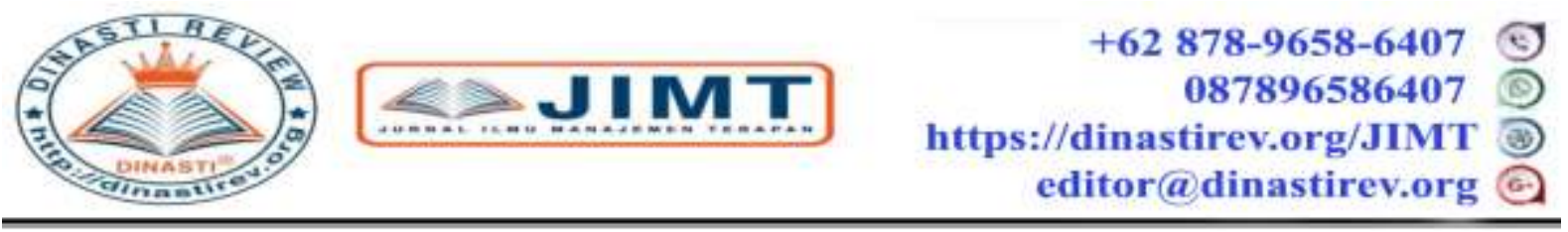

\title{
PERANAN ETIKA BISNIS DALAM BISNIS
}

\section{Bosman Butarbutar}

Universitas Mercu Buana, Jakarta, Indonesia

\begin{tabular}{|c|c|}
\hline $\begin{array}{l}\text { ARTICLE INFORMATION } \\
\text { Received: 02/12/2019 } \\
\text { Revised: } 11 / 12 / 2019 \\
\text { Issued: } 31 / 12 / 2019 \\
\text { (filled in by Editor) } \\
\text { Corresponding Author: First } \\
\text { author } \\
\text { bosmanbb79@gmail.com }\end{array}$ & $\begin{array}{l}\text { Abstrak: Penelitian ini bertujuan untuk mengetahui } \\
\text { peranan etika bisnis dalam perusahaan bisnis. Penelitian } \\
\text { ini menggunakan metode kajian kepustakaan (library } \\
\text { research), dimana kajian didasarkan pada pendapat- } \\
\text { pendapat ahli tentang etika bisnis dan peranannya dalam } \\
\text { perusahaan. Etika berbisnis ini bisa dilakukan dalam } \\
\text { segala aspek. Saling menjaga kepercayaan dalam } \\
\text { kerjasama akan berpengaruh besar terhadap reputasi } \\
\text { perusahaan tersebut, baik dalam lingkup mikro maupun } \\
\text { makro. Tentunya ini tidak akan memberikan keuntungan } \\
\text { segera, namun ini adalah wujud investasi jangka panjang } \\
\text { bagi seluruh elemen dalam lingkaran bisnis. } \\
\text { Kata Kunci : Etika Bisnis dan Perusahaan }\end{array}$ \\
\hline
\end{tabular}

\section{PENDAHULUAN}

Dalam melaksanakan bisnis tentunya etika bisnis sangat diperlukan dalam rangka pencapaian tujuan bisnis yang telah ditentukan. Kegiatan bisnis yang berlandaskan etika adalah bisnis yang dilakukan berdasarkan metoda-metoda yang baik serta cara berfikir yang sesuai dengan logika dan estetika yang berkembang di masyarakat.

Dengan demikian bisnis yang berdasarkan etika akan berjalan tanpa merugikan pihakpihak lain "Understanding what is right or wrong and acceptable or unacceptable based on organizational and societal expectations constitutes business ethics. It is an area that will shape business activity ever more in the 21st century."

Memahami apa yang benar atau salah dan dapat diterima atau tidak dapat diterima berdasarkan harapan organisasi dan masyarakat merupakan pengertian dari Etika Bisnis . Kegiatan bisnis itu sudah terbentuk dari abad ke 21, Linda Ferrell \& O.C. Ferrell (2009:6).

Etika mencakup kegiatan bisnis yang beragam dari menjaga keseimbangan kehidupan kerja untuk menilai dampak dari globalisasi. Dalam lingkungan bisnis saat ini, manajemen risiko etika akan mengarahkan organisasi Anda jauh dari krisis dan meningkatkan kesuksesan keuangan.Seperti telah dikemukakan di atas bahwa etika bisnis adalah bisnis yang dilakukan dengan metoda dan prinsip yang berlandaskan pada cara berfikir positif dalam melakukan bisnisnya. Hal ini juga berlaku dalam antisipasi risiko kegagalan yang mungkin akan dihadapi. 
Dalam rangka antisipasi risiko yang akan terjadi tetap dijalankan sesuai dengan prinsip yang menguntungkan perusahaan tanpa merugikan pihak lain, sehingg terjadi persaingan yang bersifat positif/sehat, akibatnya terjadi keselarasan dan keseimbangan yang harmonis antara pebisnis yang ada.

Saat bisnis telah memberikan kontribusi yang besar dalam kemajuan, ekonomi, sosial dan budaya, namun juga menimbulkan konsekuensi yang disebabkan oleh kegiatan perusahaan tersebut. Dalam berbagai kegiatan perusahaan dimungkinkan munculnya perilaku pelanggaran etika karena ada kecenderungan orang yang merasa dirinya paling benar dalam berbagai macam situasi. Oleh sebab itu dalam situasi apapun perlu suatu kesadaran moral, agar keputusan yang dibuat walau dalam kondisi apapun tetap bernilai etika. Dunia bisnis yang tumbuh dengan pesat menjadi tantangan maupun ancaman bagi para pelaku usaha agar dapat memenangakan persaingan dan mempertahankan kelangsungan hidup perusahaannya. Perusahaan yang ingin berkembang dan ingin mendapatkan keunggulan bersaing harus dapat menyediakan produk atau jasa yang berkualitas, harga yang murah dibandingkan pesaing, waktu penyerahan lebih cepat, dan pelayanan yang lebih baik dibandingkan pesaingnya (Margaretha, 2004).

Dalam memenangkan persaingan dalam dunia bisnis, perusahaan harus dapat mempertahankan pasar yang dimiliki, dan merebut pasar yang sudah ada, maka perusahaan dituntut untuk memiliki kemampuan dalam merencanakan strategi usaha yang ingin dijalankannya. Besarnya peluang bisnis di Indonesia telah memacu usaha-usaha berkembang di Indonesia. Munculnya berbagai macam kegiatan bisnis, menunjukkan bisnis menguntungkan. Bagaimanapun, usaha sangat dibutuhkan. Persaingan dalam usaha sangat ketat, oleh karena itu, persaingan harus dihadapi sebagai motivator untuk meningkatkan kualitas dalam memberikan yang terbaik kepada konsumen. Etika bisnis memiliki hubungan yang erat dengan kepuasan pelanggan. Etika bisnis memberikan suatu dorongan kepada pelanggan untuk menjalin ikatan hubungan yang kuat dengan perusahaan. Dalam jangka panjang ikatan seperti ini memungkinkan perusahaan untuk memahami dengan seksama harapan pelanggan serta kebutuhan mereka. Dengan demikian, perusahaan dapat meningkatkan kepuasan pelanggan di mana perusahaan memaksimumkan pengalaman pelanggan yang menyenangkan dan meminimumkan pengalaman pelanggan yang kurang menyenangkan.

Dalam keadaan persaingan ketat memperebutkan perhatian konsumen, dan dunia bisnis yang semakin kompetitif, bagian pemasaran perusahaan akan terus mencari terobosan baru melalui promosi untuk mengimbangi atau mengatasi upaya-upaya promosi oleh pesaing. Terdapat hubungan yang erat antara etika bisnis dan persaingan usaha, terdapatnya aspek hukum dan aspek etika bisnis yang sangat menentukan terwujudnya persaingan yang sehat. Munculnya persaingan yang tidak sehat disebabkan karena peranan hukum dan etika bisnis dalam persaingan usaha belum berjalan sebagaimana mestinya. Etika bisnis tidak akan dilanggar jika ada aturan dan sanksi- sanksi. Kalau semua tingkah laku yang salah dibiarkan, maka lama-kelamaan akan menjadi kebiasaan. Repotnya norma yang salah ini akan menjadi budaya. Oleh karena itu, bila ada yang melanggar aturan akan diberikan sanksi untuk memberikan pelajaran kepada yang bersangkutan, sebagai bagian dalam masyarakat, tentu bisnis tunduk pada norma-norma yang ada pada masyarakat.

Etika bisnis dalam perusahaan memiliki peran yang sangat penting, Suatu perusahaan akan berhasil bukan hanya berlandaskan moral dan manajemen yang baik saja, tetapi juga 
harus memiliki etika bisnis yang baik. Perusahaan harus dapat mempertahankan mutu serta dapat memenuhi permintaan pasar yang sesuai dengan apa yang dianggap baik dan diterima masyarakat..Perilaku tidak etis dalam kegiatan bisnis sering juga terjadi karena peluangpeluang yang diberikan oleh peraturan perundang-undangan yang kemudian disahkan dan disalah gunakan dalam penerapannya dan kemudian dipakai sebagai dasar untuk melakukan perbuatan-perbuatan yang melanggar etika bisnis. Haruslah diyakini bahwa pada dasarnya praktek etika bisnis akan selalu menguntungkan perusahaan baik untuk jangka menengah maupun jangka panjang, karena mampu mengurangi biaya akibat dicegahnya kemungkinan terjadinya friksi, baik intern perusahaan maupun dengan eksternal, mampu meningkatkan motivasi pekerja, melindungi prinsip kebebasan berniaga, mampu meningkatkan keunggulan bersaing. perusahaan yang menjunjung tinggi nilai-nilai etika bisnis, pada umumnya termasuk perusahaan yang memiliki peringkat kepuasan bekerja yang tinggi pula, terutama apabila perusahaan tidak mentolerir tindakan yang tidak etis, misalnya diskriminasi dalam sistem remunerasi atau jenjang karier. Perlu dipahami, karyawan yang berkualitas adalah aset yang paling berharga bagi perusahaan. Oleh karena itu, perusahaan harus semaksimal mungkin harus mempertahankan karyawannya.

Tata hubungan bisnis dan masyarakat yang tidak dapat dipisahkan tersebut membawa serta etika-etika tertentu dalam kegiatan bisnis, baik etika itu antara sesama pelaku bisnis maupun etika bisnis terhadap masyarakat dalam hubungan langsung maupun tidak langsung. Tanpa kita sadari, sejak keberadaan kehidupan bermasyarakat, nilai-nilai yang dianggap dapat menjadikan orang berperilaku baik dan benar merupakan sebuah kebutuhan. Keberadaan masyarakat dalam dunia bisnis menjadi sebuah indikator adanya nilai-nilai tersebut, karena tanpa adanya nilai-nilai yang bisa mempertahankan keberhasilan perusahaan, orang akan berperilaku seenaknya dan merugikan orang lain sehingga akan mengganggu jalannya perusahaan itu sendiri. Nilai-nilai tersebut tertuang dalam norma yang akan berlaku dalam masyarakat. Ada yang termasuk norma umum dan khusus. Norma umum akan berlaku umum dan univerasal, tidak kenal tempat, waktu dan lingkungan masyarakat. Artinya dimanapun, kapanpun dan di lingkungan manapun norma tersebut akan diberlakukan. Sedangkan normas khusus berlaku pada tempat, waktu dan lingkungan yang khusus, disamping juga mengatur kegiatan di bidang usaha.

Pelaku bisnis sebagai bagian dari masyarakat tidak dapat memisahkan diri dari normanorma dan nilai-nilai yang berlaku di masyarakatnya. Selain harus pula mengikuti normanorma dan nilai- nilai yang berlaku di kalangan bisnis. Ketidakpercayaan dan ketidakberdayaan yang diterima sebagian pelaku bisnis akan mempengaruhi pula ketidakpercayaan pada bangsa Indonesia secara keseluruhan. Dari segi etika bisnis, hal ini penting karena merupakan perwujudan dari nilai-nilai moral. Pelaku bisnis sebagian menyadari bahwa bila ingin berhasil dalam kegiatan bisnis, ia harus mengindahkan prinsipprinsip etika. Penegakan etika bisnis makin penting artinya dalam upaya menegakkan iklim persaingan sehat yang kondusif. Sekarang ini banyak praktek pesaing bisnis yang sudah jauh dari nilai-nilai etis, sehingga bertentangan dengan standar moral. Para pelaku bisnis sudah berani menguasai pasar komoditi tertentu dengan tidak lagi mengindahkan sopan- santun berbisnis. Keadaan ini semakin krusial sebagai akibat dari sikap Pemerintah yang memberi peluang kepada beberapa perusahaan untuk menguasai sektor industri dari hulu ke hilir.

Banyak faktor yang mempengaruhi dan menentukan kegiatan berbisnis. Sebagai kegiatan sosial, bisnis dengan banyak cara terjalin dengan kompleksitas masyarakat modern. 
Dalam kegiatan berbisnis, mengejar keuntungan adalah hal yang wajar, asalkan dalam mencapai keuntungan tersebut tidak merugikan banyak pihak. Jadi, dalam mencapai tujuan dalam kegiatan berbisnis ada batasnya. Kepentingan dan hak-hak orang lain perlu diperhatikan. Perilaku etis dalam kegiatan berbisnis adalah sesuatu yang penting demi kelangsungan hidup bisnis itu sendiri. Bisnis yang tidak etis akan merugikan bisnis itu sendiri terutama jika dilihat dari perspektif jangka panjang. Bisnis yang baik bukan saja bisnis yang menguntungkan, tetapi bisnis yang baik adalah selain bisnis tersebut menguntungkan juga bisnis yang baik secara moral. Perilaku yang baik, juga dalam konteks bisnis, merupakan perilaku yang sesuai dengan nilai-nilai moral.

Bisnis berkaitan juga dengan hukum. Terdapat banyak masalah yang muncul dalam hubungan dengan bisnis, baik pada taraf nasional maupun taraf internasional. Walaupun terdapat hubungan erat antara norma hukum dan norma etika, namun dua macam hal itu tidak sama. Ketinggalan hukum, dibandingkan dengan etika, tidak terbatas pada masalah-masalah baru, misalnya, disebabkan perkembangan teknologi. Tanpa disadari, kasus pelanggaran etika bisnis merupakan hal yang biasa dan wajar pada masa kini. Secara tidak sadar, kita sebenarnya menyaksikan banyak pelanggaran etika bisnis dalam kegiatan berbisnis di Indonesia. Banyak hal yang berhubungan dengan pelanggaran etika bisnis yang sering dilakukan oleh para pebisnis yang tidak bertanggung jawab di Indonesia. Berbagai hal tersebut merupakan bentuk dari persaingan yang tidak sehat oleh para pebisnis yang ingin menguasai pasar. Selain untuk menguasai pasar, terdapat faktor lain yang juga mempengaruhi para pebisnis untuk melakukan pelanggaran etika bisnis, antara lain untuk memperluas pangsa pasar, serta mendapatkan banyak keuntungan. Ketiga faktor tersebut merupakan alasan yang umum untuk para pebisnis melakukan pelanggaran etika dengan berbagai cara.

Tidak bisa dipungkiri, tindakan yang tidak etis yang dilakukan oleh perusahaan akan memancing tindakan balasan dari konsumen dan masyarakat dan akan sangat kontra produktif, misalnya melalui gerakan pemboikotan, larangan beredar, larangan beroperasi dan lain sebagainya. Hal ini akan dapat menurunkan nilai penjualan maupun nilai perusahaan. Sedangkan perusahaan yang menjunjung tinggi nilai-nilai etika bisnis, pada umumnya termasuk perusahaan yang memiliki peringkat kepuasan bekerja yang tinggi pula, terutama apabila perusahaan tidak mentolerir tindakan yang tidak etis, misalnya diskriminasi dalam sistem remunerasi atau jenjang karier. Berdasarkan latar belakang tersebut di atas penulis tertarik melakukan kajian tentang peranan etika bisnis dalam perusahaan bisnis.

\section{KAJIAN PUSTAKA}

Etika Bisnis. Etika (Yunani Kuno: "ethikos", berarti "timbul dari kebiasaan") menurut Wahyu dan Ostaria (2006) adalah cabang utama filsafat yang mempelajari nilai atau kualitas. Etika mencakup analisis dan penerapan konsep seperti benar, salah, baik, buruk, dan tanggung jawab. Etika adalah ilmu yang berkenaan tentang yang buruk dan tentang hak dan kewajiban moral. Menurut Bekum (2004) etika dapat didefinisikan sebagai seperangkat prinsip moral yang membedakan yang baik dari yang buruk. Etika adalah bidang ilmu yang bersifat normative karena ia berperan menentukan apa yang harus dilakukan atau tidak boleh dilakukan oleh seorang individu. Dari hasil analisis Bertens (2004:6) disimpulkan bahwa etika memiliki tiga posisi, yaitu sebagai (1) sistem nilai, yakni nilai-nilai dan norma-norma yang menjadi pegangan bagi seseorang atau suatu kelompok dalam mengatur tingkah lakunya, (2) kode etik, yakni kumpulan asas atau nilai moral, dan (3) filsafat moral, yakni 
ilmu tentang yang baik atau buruk. Dalam poin ini, akan ditemukan keterkaitan antara etika sebagai sistem filsafat sekaligus artikulasi kebudayaan. Di samping itu, filsafat menganalisa tentang mengapa dan bagaimana manusia itu hidup di dunia serta mengatur level mikrokosmos (antar manusia) dan makrokosmos (antar Alam dan Tuhan). Sebagai sistem pemikiran tentunya konsep dasar filsafat digunakan dalam mengkaji etika dalam sebuah hubungan keseimbangan antara cipta, rasa, dan karsa. Hubungan tersebut didasari landasan pemikiran bahwasanya ontologi, epistemologi, dan aksiologi.

Bisnis, Menurut Griffin dan Ebert (2008: 4) bisnis adalah organisasi yang menyediakan barang atau jasa untuk dijual dengan maksud agar mendapatkan laba. Menurut Sukirno (2010: 20) bisnis adalah kegiatan untuk memperoleh keuntungan.semua orang atau individu maupun kelompok melakukan kegiatan bisnis pastinya untuk mencari keuntungan agar kebutuhan hidup nya terpenuhi. Tidak ada orang yang melakukan bisnis untuk mencari kerugian. Menurut Madura (2010 : 2) bisnis adalah suatu badan yang diciptakan untuk menghasilkan produk barang dan jasa kepada pelangggan. Setiap bisnis mengadakan transaksi dengan orang-orang. Orang-orang itu menanggung akibat karena bisnis tersebut, mereka. Kerja sama lintas fungsional di dalam bisnis adalah dengan menekankan kebutuhan para manajer dari area fungsional yang berbeda untuk memaksimalkan laba dalam mencapai tujuan bersama.

\section{METODE PENELITIAN}

Jenis Penelitian, Penelitian ini menggunakan metode kajian kepustakaan (library research), dimana kajian didasarkan pada pendapat- pendapat ahli tentang etika bisnis dan peranannya dalam perusahaan. Penelitian Kepustakaan (library research), yaitu mengumpulkan data sekunder atau data yang diperoleh dari data yang telah dibukukan, baik berupa laporan-laporan maupun hasil penelitian terdahulu. Penelitian ini bertujuan untuk mengetahui peranan etika bisnis dalam perusahaan bisnis.

\section{HASIL DAN PEMBAHASAN}

Etika bisnis adalah segmen etika terapan yang mencoba untuk mengontrol dan memeriksa pengaturan moral dan etika perusahaan. Ia juga mendalami seberapa baik atau buruk badan usaha membahas masalah-masalah moral dan etika dan menunjukkan apa yang salah dalam proses alami mereka. Ini mencakup semua aspek bisnis dari produksi untuk administrasi, keuangan dan pemasaran. Hal ini juga berlaku untuk berbagai industri dan dapat deskriptif atau normatif dalam disiplin. Adapun etika bisnis perusahaan memiliki peran yang sangat penting, yaitu untuk membentuk suatu perusahaan yang kokoh dan memiliki daya saing yang tinggi serta mempunyai kemampuan menciptakan nilai (value-creation) yang tinggi, dimana diperlukan suatu landasan yang kokoh untuk mencapai itu semua. Dan biasanya dimulai dari perencanaan strategis, organisasi yang baik, sistem prosedur yang transparan didukung oleh budaya perusahaan yang handal serta etika perusahaan yang dilaksanakan secara konsisten dan konsekuen. 


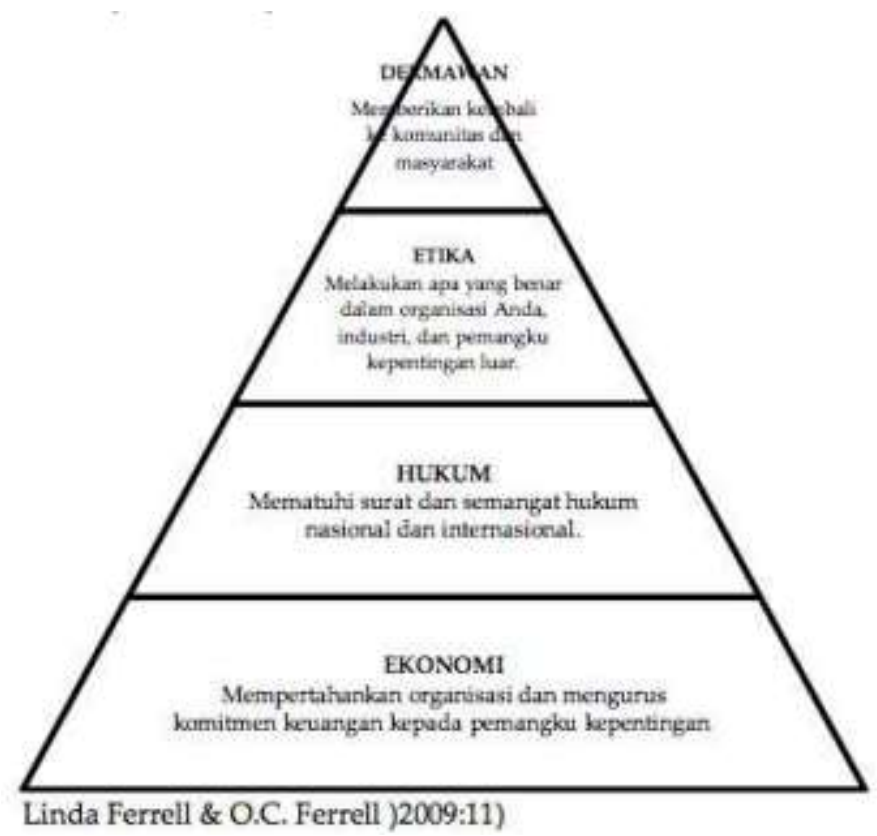

Gambar 1. Piramida Tanggung Jawab Sosial Perusahaan

Sudut pandang ekonomis. Bisnis adalah kegiatan ekonomis. Yang terjadi disini adalah adanya interaksi antara produsen/perusahaan dengan pekerja, produsen dengan konsumen, produsen dengan produsen dalam sebuah organisasi. Kegiatan antar manusia ini adalah bertujuan untuk mencari untung oleh karena itu menjadi kegiatan ekonomis. Pencarian keuntungan dalam bisnis tidak bersifat sepihak, tetapi dilakukan melalui interaksi yang melibatkan berbagai pihak. Dari sudut pandang ekonomis, good business adalah bisnis yang bukan saja menguntungkan, tetapi juga bisnis yang berkualitas etis. Tanggung jawab ekonomi organisasi - kontribusinya terhadap perekonomian. Dari hari pertama, bisnis harus layak, membuat keuntungan bagi pemegang saham dan pemilik, yang pada gilirannya mendorong perekonomian yang lebih luas. Bisnis yang gagal memenuhi responsibilitas ekonomi mereka menghambat pertumbuhan ekonomi, dan mengurangi kemungkinan bahwa perusahaan asing akan berinvestasi.

Sudut pandang etika. Dalam bisnis, berorientasi pada profit, adalah sangat wajar, akan tetapi jangan keuntungan yang diperoleh tersebut justru merugikan pihak lain. Tidak semua yang bisa kita lakukan boleh dilakukan juga. Kita harus menghormati kepentingan dan hak orang lain. Pantas diperhatikan, bahwa dengan itu kita sendiri tidak dirugikan, karena menghormati kepentingan dan hak orang lain itu juga perlu dilakukan demi kepentingan bisnis kita sendiri.

Sudut pandang Hukum, bisa dipastikan bahwa kegiatan bisnis juga terikat dengan "Hukum" Hukum Dagang atau Hukum Bisnis, yang merupakan cabang penting dari ilmu hukum modern. Dan dalam praktek hukum banyak masalah timbul dalam hubungan bisnis, pada taraf nasional maupun international. Seperti etika, hukum juga merupakan sudut pandang normatif, karena menetapkan apa yang harus dilakukan atau tidak boleh dilakukan. Dari segi norma, hukum lebih jelas dan pasti daripada etika, karena peraturan hukum dituliskan hitam atas putih dan ada sanksi tertentu bila terjadi pelanggaran. anggung jawab hukum; ini adalah hukum yang mengatur cara menjalankan usaha. Bisnis diwajibkan untuk mematuhi undang-undang atau denda wajah diberlakukan oleh pemerintah. Ketika masyarakat memiliki harapan bahwa bisnis tidak memenuhi, atau ketika berpikir bahwa 
bisnis bertindak dengan cara yang tidak adil, mungkin butuh keluhan untuk pengadilan. Legislasi kemudian dapat diteruskan yang mengatur aktivitas tersebut. Kebanyakan hukum bisnis tidak memulai sebagai undang-undang, namun masalah yang etis yang menarik keberatan yang serius dan berulang.

Fungsi dan Etika Bisnis terhadap Perusahaan, setelah mengetahui betapa pentingnya etika yang harus diterapkan pada perusahaan bisnis, tentunya etika memiliki fungsi yang sangat berpengaruh terhadap kemajuan perusahaan itu sendiri. Permasalahan etika bisnis yang terjadi di perusahaan bervariasi antara fungsi perusahaan yang satu dan fungsi perusahaan lainnya. Hal ini terjadi karena operasi perusahaan sangat terspesialisasi dalam berbagai bidang profesi, sehingga setiap fungsi perusahaan cenderung memiliki masalah etika tersendiri. Berikut ini akan dibahas berbagai permasalahan etika bisnis yang terjadi di beberapa bidang fungsi perusahaan, yaitu: etika bisnis di bidang akuntansi (accounting ethics), keuangan (finance ethics), produksi dan pemasaran (production and marketing ethics), sumber daya manusia (human resources ethics), dan teknologi informasi (information technology ethics)

Sanksi Pelanggaran Yang Akan Diterima Jika Perusahaan Tidak Menerapkan Etika Didalam Bisnisnya, pelanggaran etika bisa terjadi di mana saja, termasuk dalam dunia bisnis. Untuk meraih keuntungan, yang sebagaimana terdapat dalam Pasal 22 yang berbunyi "Pelaku usaha dilarang bersekongkol dengan pihak lain untuk mengatur dan atau menentukan pemenang tender sehingga dapat mengakibatkan terjadinya persaingan usaha tidak sehat". Pasal ini menjelaskan tentang Tender adalah tawaran mengajukan harga untuk memborong suatu pekerjaan, untuk mengadakan barang- barang, atau untuk menyediakan jasa. Dan unsur dari bersekongkol itu sendiri adalah kerjasama antara dua pihak atau lebih, secara terangterangan maupun diam-diam melakukan tindakan penyesuaian dokumen dengan peserta lainnya, membandingkan dokumen tender sebelum penyerahan, menciptakan persaingan semu, menyetujui dan atau memfasilitasi terjadinya persekongkolan, tidak menolak melakukan suatu tindakan meskipun mengetahui atau sepatutnya mengetahui bahwa tindakan tersebut dilakukan untuk mengatur dalam rangka memenangkan peserta tender tertentu, pemberian kesempatan eksklusif oleh penyelenggara tender atau pihak terkait secara langsung maupun tidak langsung kepada pelaku usaha yang mengikuti tender, dengan cara melawan hukum. Hal diatas adalah pelanggaran yang akan diterima kepada perusahaan yang tidak menerapkan etika didalam bisnisnya karena memiliki unsur kecurangan. Hal lain yang menjadikan pelanggaran terhadap perusahaan yang tidak menerapkan etika didalam bisnisnya adalah pegawai perusahaan yang melakukan pelanggaran Pedoman Etika Bisnis dan Etika Kerja (Code of Conduct) sesuai dengan ketentuan yang berlaku. Pengenaan sanksi atas bentuk-bentuk pelanggaran yang dilakukan oleh Komisaris dan Direksi, berpedoman pada anggaran dasar perusahaan dan keputusan RUPS. Sedangkan pengenaan sanksi terhadap pegawai perusahaan dilakukan sesuai dengan kesepakatan dalam Peraturan Disiplin Pegawai (PDP) maupun aturan kepegawaian yang berlaku. Pelaporan adanya dugaan pelanggaran yang dilakukan oleh pegawai tanpa disertai dengan bukti-bukti pelanggaran dapat dikenakan sanksi sesuai dengan ketentuan yang berlaku. Dari contoh pelanggaran diatas kita dapat mengambil kesimpulan bahwa yang menjadikan perusahaan untuk menerapkan etika di dalam bisnisnya bukanlah dari perusahaan Template Artikel Jurnal Ilmiah Manajemen itu sendiri melainkan adanya kejujuran dari para pegawai yang bekerja di perusahaan tersebut sehingga dapat 
menciptakan suasana kerja yang damai serta menjadikan perusahaan tersebut menjadi perusahaan yang menerapkan etika didalam bisnisnya.

Etika Bisnis di Indonesia, di Indonesia, etika bisnis merupakan sesuatu yang lama tetapi sekaligus baru. Sebagai sesuatu yang bukan baru, etika bisnis eksis bersamaan dengan hadirnya bisnis dalam masyarakat Indonesia, artinya usia etika bisnis sama dengan usia bisnis yang dilakukan oleh masyarakat Indonesia.

\section{KESIMPULAN}

Di dalam persaingan dunia usaha yang sangat ketat ini, etika bisnis merupakan sebuah harga mati, yang tidak dapat ditawar lagi. Dalam zaman keterbukaan dan luasnya informasi saat ini, baik- buruknya sebuah dunia usaha dapat tersebar dengan cepat dan luas. Memposisikan karyawan, konsumen, pemasok, pemodal dan masyarakat umum secara etis dan jujur adalah satu-satunya cara supaya dapat bertahan di dalam dunia bisnis saat ini. Ketatnya persaingan bisnis menyebabkan beberapa pelaku bisnisnya kurang memperhatikan etika dalam bisnis.

Etika bisnis mempengaruhi tingkat kepercayaan atau trust dari masing-masing elemen dalam lingkaran bisnis. Pemasok (supplier), perusahaan, dan konsumen, adalah elemen yang saling mempengaruhi. Masing-masing elemen tersebut harus menjaga etika, sehingga kepercayaan yang menjadi prinsip kerja dapat terjaga dengan baik.

Etika berbisnis ini bisa dilakukan dalam segala aspek. Saling menjaga kepercayaan dalam kerjasama akan berpengaruh besar terhadap reputasi perusahaan tersebut, baik dalam lingkup mikro maupun makro. Tentunya ini tidak akan memberikan keuntungan segera, namun ini adalah wujud investasi jangka panjang bagi seluruh elemen dalam lingkaran bisnis. Oleh karena itu, etika dalam berbisnis sangatlah penting.

\section{DAFTAR RUJUKAN}

Anoraga, Pandji. Janti, Sugiastuti. (1996). Pengantar Bisnis Modern, Kajian Dasar Manajemen Perusahaan. PT. Dunia Pustaka Jaya, Jakarta.

Bekum Rafik Issa, (2004). Etika Bisnis Islami(Terjemahan Muhammad). Pustaka Belajar, Yokyakarta.

Bertens, K. (2004). Etika. Gramedia. Jakarta. B.F. Skinner. (1938). The Behavior of Organisms: An ExperimentalAnalysis.

Cambridge, Massachusetts: B.F. Skinner Foundation.ISBN 1-58390-007-1,ISBN 0-87411487-X.

Departemen Pendidikan dan Kebudayaan. (2009). Kamus Besar Bahasa Indonesia, edisi kedua. Balai Pustaka. Jakarta.

Griffin, Ricky W dan Ebert, Ronald J. (2008). Bisnis ,ed 8 jilid 1. Erlangga. Jakarta.

Madura Jeff, (2001).Pengantar Bisnis. Edisi Pertama. Salemba Empat, Jakarta.

Muhammad Abdul Ghani, (2005). The Sprituality in Business, PENA. Jakarta

Straub, J.T. \& Attner, R.K. (1994). Introduction to Business. California: Wadworth Publishing Company.

Sukirno Sadono. (2010). Makroekonomi : Teori Pengantar.Edisi Ketiga. PT. Raja Grasindo Perseda. Jakarta.

Wahyu, Y. Istiyono dan Ostaria Silaban. (2006). Kamus Pintar Bahasa Indonesia. Kharisma 
Publishing Group. Batam.

Yusanto M.I dan M.K. Widjajakusuma. 2002. Menggagas Bisnis Islami Gema Insani, Jakarta. 